\title{
Darwinizm a problem zła *
}

Wielu dzisiejszych darwinistów żywi przekonanie, że jeśli przyjmuje się teorię ewolucji drogą doboru naturalnego, to nie można być szczerze wierzącym chrześcijaninem. Najbardziej skrajnym tego przykładem jest najzagorzalszy angielski ateista, Richard Dawkins. Ten oxfordzki biolog oświadczył niegdyś: „Jestem darwinistą, bo jedyną alternatywą dla darwinizmu jest lamarkizm albo wiara w Boga-Stwórcę - ani jedno, ani drugie nie daje podstaw do naukowego wyjaśnienia zagadki życia. Daje ją albo darwinizm, albo coś, czego jeszcze nie wymyślono". ${ }^{1} \mathrm{~W}$ innym miejscu Dawkins stwierdził: „Świat, który obserwujemy, ma dokładnie takie właściwości, jakich należałoby oczekiwać, gdyby nie było żadnego planu, celu, dobra ani zła, tylko ślepa, bezwzględna obojętność". ${ }^{2}$

\footnotetext{
* Michael Ruse, „Darwinism and the Problem of Evil”, w: William A. Dembski (ed.), Darwin's Nemesis: Phillip Johnson and the Intelligent Design Movement, InterVarsity Press, Downers Grove, Illinois 2006, s. 139-150. Za zgodą Autora i Wydawnictwa z języka angielskiego przełożyła Aleksandra Bulaczek. Recenzent: Marek RemBIERz, Zakład Edukacji Integralnej i Obywatelskiej Uniwersytetu Śląskiego w Katowicach.

Copyright (C) 2006 by William A. Dembski. Translated and used by permission of InterVarsity Press, P.O. Box 1400, Downers Grove, IL 60515-1426, www.ivpress.com.

${ }^{1}$ Richard Dawkins, w: John Brockman (red.), Trzecia kultura, przeł. Piotr Amsterdamski i in., Wydawnictwo CiS, Warszawa 1996, s. 114.

${ }^{2}$ Richard Dawkins, Rzeka genów, przeł. Marek Jannasz, Science Masters, Wydawnictwo CiS i Oficyna Wydawnicza MOST, Warszawa 1995, s. 193.
} 
Dawkins wielokrotnie mówił o „tchórzliwej słabości umysłu, [która] dotyka skądinąd racjonalnych ludzi przy konfrontacji z religiami o długich tradycjach”. ${ }^{3}$ Jego zdaniem „Poglądy na Wszechświat kształtowane przez religię raziły zawsze małostkowością, patosem w złym guście i ograniczonością w porównaniu $\mathrm{z}$ tym, jaki Wszechświat jest naprawdę. Kosmos w nauczaniu zinstytucjonalizowanych religii to mały, zabudowany ze wszystkich stron rynek średniowiecznego prowincjonalnego miasteczka". ${ }^{4}$ Dawkins jest dumny ze swych surowych osądów: „Uważa się mnie za swego rodzaju fanatyka. Wynika to częściowo z mojej — niejednokrotnie głośno objawianej niechęci wobec wszelkich bezsensownych przesądów - natury religijnej. Wszystkie one, moim zdaniem, wiodą na manowce". ${ }^{5}$

\section{Powtórzona taśma życia}

Tak się składa, że nie mam bardziej pozytywnego nastawienia względem wiary religijnej niż Dawkins. Jednak nie to jest przedmiotem mojego artykułu. Chciałbym natomiast rozważyć relację między darwinizmem a religią, zwłaszcza między darwinizmem a chrześcijaństwem. Problematyka ta obejmuje wiele zagadnień, jednak nie wszystkie zostaną tu rozpatrzone. Według mnie jedną z najbardziej palących kwestii jest problem przygodności. ${ }^{6}$ Jeśli chrześcijaństwo prawdziwie ujmuje rzeczywistość, to istnienie ludzi (lub istot przypominających człowieka) nie może być jedynie przypadkiem, ale w pewnym sensie musi być nieuniknione lub konieczne. Nieżyjący już Stephen Jay Gould przedstawił tę kwestię, jak zawsze, niezwykle przejrzyście. Na-

\footnotetext{
${ }^{3}$ Richard Dawkins, „Obscurantism to the Rescue”, Quarterly Review of Biology 1997, vol. 72 , s. 397.

${ }^{4}$ Dawkins, w: Brockman (red.), Trzecia kultura..., s. 114.

${ }^{5}$ Dawkins, w: Brockman (red.), Trzecia kultura..., s. 113.

${ }^{6}$ Por. Michael Ruse, On a Darkling Plain: The Evolution-Creation Struggle, Harvard University Press, Cambridge, Massachusetts 2005.
} 
wiązując do komety, która uderzyła w Ziemię około sześćdziesiąt pięć milionów lat temu, przyczyniając się do zagłady dinozaurów, pisał:

Skoro ewolucja dinozaurów nie biegła w kierunku wykształcenia znacznie większych mózgów i skoro uniemożliwiać to mogła już sama budowa gadów, $[\ldots]$ to musimy przyjąć, że na naszej planecie w ogóle nie doszłoby do wyewoluowania świadomości, gdyby kosmiczna katastrofa ich nie unicestwiła. Całkiem dosłownie zawdzięczamy swoje istnienie, jako duże i myślące ssaki, naszym szczęśliwym gwiazdom. ${ }^{7}$

W swojej nowej książce, Life's Solutions: Inevitable Humans in a Lonely Universe [Rozwiązania życia: konieczność istnienia ludzi w osamotnionym Wszechświecie], brytyjski paleontolog Simon Conway Morris daje odpowiedź na ten zarzut. Sugeruje, że pojawienie się człowieka na Ziemi było daleko bardziej pewne - nawet w świetle darwinowskiej ewolucji — niż można by się było tego spodziewać. Wskazując na fakt, że ewoluujące życie szuka nisz, a rozmaite formy życia często znajdują te same nisze (konwergencja), Conway Morris stwierdza:

Jeśli mózgi mogą niezależnie zwiększyć swoją objętość, stając się neuronowymi maszynami zdolnymi do funkcjonowania $\mathrm{w}$ wysoce skomplikowanych warunkach środowiskowych, to być może istnieją inne podobieństwa, inne konwergencje, które prowadzą pewne grupy ku złożoności. Czy historia percepcji zmysłowej może być wskazówką, że z biegiem czasu ewolucja nieuchronnie doprowadzi nie tylko do wykształcenia takich właściwości jak inteligencja, ale również do innych złożonych zjawisk, takich jak rolnictwo i kultura, które postrzegane są zwykle jako prerogatywy człowieka? Możemy być wyjątkowi, ale - paradoksalnie - cechy określające naszą wyjątkowość mogą być wpisane w proces ewolucji. Innymi słowy, gdyby ludzie nie wyewoluowali, to prędzej czy później powstałoby coś mniej lub bardziej podobnego do człowieka. ${ }^{8}$

Nie jestem pewien, czy będzie to ostatnie słowo w tej kwestii. Uważam jednak, że Conway Morris zaproponował przynajmniej punkt

\footnotetext{
${ }^{7}$ Stephen Jay Gould, Wonderful Life: The Burgess Shale and the Nature of History, W.W. Norton, New York 1989, s. 318.

${ }^{8}$ Simon Conway Morris, Life's Solution: Inevitable Humans in a Lonely Universe, Cambridge University Press, Cambridge 2003, s. 196.
} 
wyjścia dla krytyki poglądów takich uczonych jak Gould, według którego życie jest tworem przypadku i gdyby puścić taśmę życia od nowa, to nigdy nie powstanie coś, co w najmniejszym nawet stopniu przypominałoby człowieka.

\section{Czy ateizm jest możliwy?}

Kolejna ważna kwestia dotyczy możliwości odrzucenia chrześcijaństwa ze względu na darwinizm. Nie będę szeroko omawiał tego tematu, gdyż poświęciłem mu książkę Darwin and Design: Does Evolution Have a Purpose? [Darwin a projekt: czy ewolucja ma cel?]. Grecy postawili ludzi niewierzących przed problemem. Jest coś uderzającego w świecie, zwłaszcza w świecie organizmów. Nie są one czymś bezładnym, lecz są złożone i uporządkowane. Działają, funkcjonują, tworzą harmonijną całość, słowem - ukazują to, co Arystoteles nazwał „przyczynami celowymi”. Części ciała, jak na przykład ręka lub oko, nie istnieją ot tak, lecz przeznaczone są do określonych zadań lub celów, jak chwytanie czy widzenie.

Oczywistym jest, że rozważając przyczyny konstrukcji ręki lub oka, musimy wziąć pod uwagę takie czynniki jak rozwój embrionalny, nie jest to jednak wystarczające. W platońskim dialogu Fedon, opisującym śmierć Sokratesa, skazany filozof zastanawia się, dlaczego człowiek rośnie:

Przedtem to niejedno wiedziałem jasno, tak się przynajmniej mnie samemu zdawało i drugim, a wtedy od tych rozważań wszystkich tak mnie zaślepiło gwałtownie, że przestałem wiedzieć i to, co mi się przedtem zdawało, że wiem, to o różnych rzeczach, a między innymi i o tym, przez co to człowiek rośnie. To, zdawało mi się przedtem, dla każdego jest jasne, że przez jedzenie i picie. Bo skoro z pokarmów do mięsa przybędzie mięsa, a kościom przybędzie kości, i tak samo tym innym przybędzie każdemu tego, co mu pokrewne, wtedy kupka zrazu mała, zrobi się z czasem duża i tak się mały człowiek robi wielkim. ${ }^{9}$

\footnotetext{
${ }^{9}$ Platon, Fedon, w: Platon, Dialogi, t. 1, przeł. Władysław Witwicki, Wydawnictwo Antyk, Kęty 1999, 96 D.
} 
Jednak w dalszej części dialogu przemawiający ustami Sokratesa Platon stwierdza, że tego rodzaju wyjaśnienie jest niewystarczające. Nie jest ono niewłaściwe, lecz niekompletne. Należy bowiem odpowiedzieć na pytanie, dlaczego ktoś miałby rosnąć. Jak to jest, że wykształciły się tak niezbędne narządy jak ręce i oczy? Niekierowane, ślepe siły nie mogły ich stworzyć. Do zaistnienia takich struktur potrzeba bowiem szczególnego rodzaju sił. Ich wyjaśnienie wymaga odwołania się do myślącej czy inteligentnej istoty. Ręka i oko funkcjonują, ponieważ jakaś istota (czy może Istota) pomyślała o ludzkich potrzebach i stworzyła - zaprojektowała - te narządy tak, by pełniły określone zadania lub cele. Jak mówił Sokrates: „rozum, pięknie porządkujący, porządkuje wszystko i wszystkich tak układa, jak może być najlepiej. Więc gdyby ktoś chciał wykryć przyczynę czegokolwiek, jak ono powstaje albo ginie, albo istnieje, ten powinien się dowiedzieć, jak właściwie temu lub owemu najlepiej istnieć, czy czegoś innego doznawać, czy działać". ${ }^{10}$

Zgadzam się z Richardem Dawkinsem, który uważa, że organizacja istot żywych wymaga wyjaśnienia. ${ }^{11}$ Nim teoria Darwina ujrzała światło dzienne, jedynym odpowiednim wyjaśnieniem był Bóg. Dawid Hume przedstawił miażdżącą krytykę kosmologicznego dowodu na istnienie Boga. Zwrócił on uwagę, że w najlepszym wypadku przez analogię do ludzkich artefaktów - powinniśmy wnosić o grupie projektantów pracujących nad stworzeniem modelu świata, który byłby tylko jednym $\mathrm{z}$ wielu modeli, począwszy od prymitywnych, a skończywszy na znacznie bardziej doskonałych niż nasz. W najgorszym zaś wypadku, mając na uwadze zło i cierpienie w świecie, nikt nie mógłby sądzić, że projektantem jest chrześcijański Bóg miłości: „jakież katusze zadaje nam podagra, kamienie, migrena, ból zębów, reumatyzm, wszystko jedno, czy uszkodzenie zwierzęcego mechani-

\footnotetext{
${ }^{10}$ Platon, Fedon..., 97 C.

${ }^{11}$ Por. Richard DAwKINS, Ślepy zegarmistrz, czyli jak ewolucja dowodzi, że świat nie został zaplanowany, przeł. Antoni Hoffman, Biblioteka Myśli Współczesnej, Państwowy Instytut Wydawniczy, Warszawa 1994.
} 
zmu jest niewielkie czy nieuleczalne!" ${ }^{12}$ Jednak nawet Hume, pomimo swego sceptycyzmu, zdawał sobie sprawę, że przyczyny celowe wymagają szczególnego rodzaju wyjaśnienia. Jeżeli mamy przed sobą tezę, że „przyczyna lub przyczyny panujacego we wszechświecie porzadku pozostaja prawdopodobnie w jakiejśs dalekiej analogii do ludzkiej inteligencji”, to „cóż więcej uczynić może człowiek najbardziej nawet dociekliwy, myślący i bogobojny, jak tezę tę, ilekroć się z nią zetknie, jasno filozoficznie zaakceptować i wierzyć, że argumenty, na których się zasadza, przeważają nad zarzutami, które przeciw niej przemawiają?" 13

Wszystko to zostało przekreślone przez Darwina. W swym epokowym dziele $\mathbf{O}$ powstawaniu gatunków argumentował on na rzecz ewolucyjnego pochodzenia wszystkich żywych istot, w tym ludzi. Zwierzęta i rośliny, zarówno te żyjące, jak i wymarłe, powstały z kilku pierwotnych, prymitywnych form życia w wyniku długiego, powolnego, naturalnego (czyli zachodzącego $\mathrm{w}$ zgodzie $\mathrm{z}$ prawami przyrody) procesu rozwoju. Darwin opisał też ewolucyjny mechanizm doboru naturalnego, prowadzący do przetrwania tych organizmów, które są lepiej przystosowane do warunków środowiska niż inne. Jako pierwszy wskazał i udowodnił, że między organizmami toczy się nieustanna walka o byt.

Walka o byt jest nieuniknionym następstwem faktu, że wszystkie istoty organiczne wykazują dążność do szybkiego tempa rozmnażania się. Wszelkie istoty produkujące w ciągu swego życia kilka jaj lub nasion muszą w jakimś okresie swego życia, w jakiejś porze lub w jakimś szczególnym roku ulegać zniszczeniu, w przeciwnym razie liczebność ich na skutek prawa postępu geometrycznego wzrosłaby do tak olbrzymich rozmiarów, że żaden kraj nie byłby w stanie ich wyżywić. Dlatego też, ponieważ rodzi się zawsze więcej osobników, niż ich może wyżyć, musi w każdym przypadku następować walka o byt albo pomiędzy osobnikami tego samego gatunku, albo między osobnikami rozmaitych gatun-

\footnotetext{
${ }^{12}$ Dawid Hume, Dialogi o religii naturalnej, w: Dawid Hume, Dialogi o religii naturalnej. Naturalna historia religii, przeł. Anna Hochfeldowa, Biblioteka Klasyków Filozofii, Państwowe Wydawnictwo Naukowe, Warszawa 1962, s. 95-96.

${ }^{13}$ Hume, Dialogi o religii naturalnej..., s. 134-135.
} 
ków czy też wreszcie z fizycznymi warunkami życia. Jest to teoria Malthusa, zastosowana w spotęgowanej sile do całego królestwa zwierzęcego i roślinnego, nie może bowiem tu zachodzić sztuczne zwiększanie ilości pokarmu ani też roztropne wstrzymywanie się od małżeństw. ${ }^{14}$

\section{O doborze naturalnym Darwin pisał:}

Weźmy tylko pod uwagę, jak nieskończonym szeregiem drobnych odchyleń cech indywidualnych różnią się wytwory naszej hodowli, a w mniejszym stopniu organizmy żyjące $\mathrm{w}$ stanie natury i jak potężna jest ich dążność do dziedziczenia. Słusznie można powiedzieć, że pod wpływem udomowienia cała organizacja staje się w pewnym stopniu plastyczna. [...] Pamiętajmy też, jak nieskończenie skomplikowane i ściśle przystosowane są wzajemne stosunki istot organicznych do siebie i do fizycznych warunków życia, jak więc nieskończenie rozmaite zmiany budowy mogą być korzystne dla każdej istoty przy zmianie warunków życia. Czyż można tedy widząc, że zmiany korzystne dla człowieka niewątpliwie powstawały, uważać za nieprawdopodobne, że w wielu następujących po sobie pokoleniach powstaną jakieś zmiany w pewien sposób korzystne dla każdej istoty organicznej $\mathrm{w}$ wielkiej i skomplikowanej walce o życie? Jeżeli zaś tak się dzieje, to czyż możemy wątpić (biorąc pod uwagę, że rodzi się daleko więcej osobników, niż się ich może utrzymać przy życiu), że osobniki mające jakąkolwiek, chociażby drobną przewagę nad innymi będą miały największe widoki przetrwania i pozostawienia potomstwa? Z drugiej strony, możemy być pewni, że wszelka zmiana, chociażby w najmniejszym stopniu szkodliwa, musi ulec koniecznie zagładzie. Otóż to utrzymywanie się korzystnych dla osobnika różnic i odmian oraz zagładę szkodliwych nazwałem ,doborem naturalnym”. ${ }^{15}$

Podzielam zdanie Dawkinsa, że dobór naturalny jest głównym mechanizmem, na jaki powołują się współcześni ewolucjoniści, chcąc wyjaśnić niektóre interesujące lub ważne aspekty świata ożywionego. Ponadto zgadzam się z tym, co z pewnością było intencją Darwina, a mianowicie, że dobór naturalny przemawia nie tylko na rzecz ewolucji, ale mówi też coś o naturze organizmów. W szczególności wyjaśnia przyczyny celowe, czyli to, co Darwin najczęściej nazywał „,przy-

\footnotetext{
${ }^{14}$ Karol DARwin, O powstawaniu gatunków drogą doboru naturalnego, czyli o utrzymaniu się doskonalszych ras w walce o byt, przeł. Szymon Dickstein i Józef Nusbaum, De Agostini Polska \& Ediciones Altaya Polska, Warszawa 2001, s. 76.

${ }^{15}$ DARwin, O powstawaniu gatunków..., s. 91-92.
} 
stosowaniem". Jedne organizmy zyskały przewagę nad innymi, ponieważ wykształciły cechy, których nie miały stworzenia pokonane w walce o byt. Oko i ręka, wzrok i chwytność to rozwiązania sprzyjające przetrwaniu. Co więcej, w świetle teorii Darwina zaistniałe cechy nie były zamierzone czy bezpośrednio zaprojektowane. Angielski przyrodnik nie potrafił wytłumaczyć natury i genezy zmian organicznych, bez których nie mogłaby dokonywać się ewolucja. Domyślał się jednak, że są one całkowicie naturalne i niekierowane, a potwierdzili to — w erze DNA — współcześni ewolucjoniści. Za przystosowanie organizmów do środowiska odpowiada przyrodniczy mechanizm dobór naturalny oddziałujący na rezultaty niekierowanych zmian. Przyczyny celowe znalazły więc wyjaśnienie naturalistyczne.

\section{Czy ateizm jest konieczny?}

Zgadzam się z Dawkinsem, że dzięki Darwinowi - i tylko dzięki niemu — można być w pełni usatysfakcjonowanym intelektualnie ateistą. Ale czy trzeba nim być? Czy porządny darwinista powinien być ateistą? Dawkins i wielu innych właśnie tak uważa. Chociaż ludzie mogą szczerze przyjmować zarówno darwinizm, jak i chrześcijaństwo, to jednak szczerość nie wystarczy. Zdaniem Dawkinsa, będąc darwinistami, powinni odrzucić chrześcijaństwo. Jerry Coyne, biolog ewolucyjny z Chicago University, wyraża opinię wielu, stwierdzając: ,jeśli ktoś stawia chrześcijaństwu takie same wymogi empiryczne, jakie naukowcy zwykli stawiać darwinizmowi, to religia na tym traci: mamy znacznie więcej dowodów na istnienie dinozaurów niż na boskość Chrystusa". ${ }^{16}$ Coyne, recenzując moją książkę Can a Darwinian Be

a Christian? [Czy darwinista może być chrześcijaninem?], w której udzielam twierdzącej odpowiedzi na postawione w jej tytule pytanie, zacytował żartobliwe słowa Georga Orwella: „trzeba należeć do inteli-

\footnotetext{
${ }^{16}$ Jerry CoYNe, „Intergalactic Jesus”, London Review of Books 2002, http://www.lrb.co.uk /v24/n09/jerry-coyne/intergalactic-jesus.
} 
gencji, aby wierzyć w coś takiego. Żaden zwykły człowiek nie może być aż takim głupcem". ${ }^{17}$

Oczywiście, jeśli chrześcijaństwo utożsami się z prymitywną, dosłowną interpretacją Biblii, a w szczególności pierwszych rozdziałów Księgi Rodzaju, to sprawa jest zamknięta. Co jednak, jeśli ktoś interpretuje Pismo Święte, zwłaszcza Stary Testament, w sposób bardziej subtelny? Pomimo całej emocjonalnej odrazy Dawkinsa wobec religii, jego wniosek nie opiera się na milczących i niesprawdzonych przesłankach, lecz ma mocną podstawę, mianowicie stary argument $\mathrm{z}$ istnienia zła w świecie. Dawkins (podobnie jak kiedyś Darwin) uważa, że dzięki teorii doboru naturalnego argument ten nabrał większej mocy. Tuż po opublikowaniu O powstawaniu gatunków Karol Darwin pisał do swojego amerykańskiego przyjaciela i zwolennika, Asy Graya:

A teraz to samo zagadnienie $\mathrm{z}$ teologicznego punktu widzenia. Sprawa ta jest zawsze dla mnie bolesna. Uwikłałem się. Pisząc, nie miałem ateistycznych intencji. Lecz wyznaję, że nie umiem dostrzec dookoła nas celowości i dobrodziejstw tak wyraźnie jak inni i jak bym sam sobie tego życzył. Wydaje mi się, że jest zbyt wiele nieszczęść na tym świecie. Nie mogę uwierzyć, aby miłosierny i wszechmocny Bóg miał celowo stworzyć gąsieniczniki [Ichneumonidae] z osobliwą zaiste intencją, aby żywiły się one żywym ciałem gąsienic; albo kota, aby musiał igrać z myszą. Nie uznając tego, nie widzę konieczności przyjęcia, że oko zostato celowo zaplanowane. ${ }^{18}$

Dawkins podziela zdanie Darwina. Nawet jeśli Bóg istnieje, to w niczym nie przypomina Boga chrześcijan: jest bezduszny, niesprawiedliwy i zupełnie obojętny.

Gdyby Natura znała co to współczucie, wykazałaby chociaż minimum dobrej woli i zadbała o to, by nieszczęsna gąsienica została przynajmniej znieczulana,

\footnotetext{
${ }^{17}$ George Orwell (cyt. za: Coyne, „Intergalactic Jesus...”).

${ }^{18}$ List Karola Darwina do Asy Graya z 22 maja 1860 roku, w: Karol Darwin, Autobiografia i wybór listów. Dzieła wybrane, t. 8, przeł. A. Iwanowska, A. Krasicka, J. Półtowicz i S. Skowron, Biblioteka Klasyków Biologii, Państwowe Wydawnictwo Rolnicze i Leśne, Warszawa 1960, s. 217.
} 
zanim będzie zjadana od środka. Natura nie jest jednak ani współczująca, ani bezduszna. Nie znajduje upodobania w cierpieniu żywych stworzeń, ani też się nim nie przejmuje. Natura, w ten czy inny sposób, może starać się oddziaływać na cierpienie wyłącznie w sytuacji, gdy ma ono wpływ na przetrwanie DNA. Nietrudno byłoby wymyślić gen znieczulający gazelę tuż przed rozszarpaniem na strzępy przez geparda. Czy jednak taki gen miałby szanse rozprzestrzenić się w następnych pokoleniach gazel w procesie doboru naturalnego? Nie, chyba że w jakiś sposób znieczulenie gazeli tuż przed śmiercią mogłoby zwiększyć szanse tego genu na przetrwanie w organizmach jej potomków. Raczej trudno sobie coś takiego wyobrazić. Dlatego też mamy pełne podstawy, by przypuszczać, że gazele przed śmiercią nie są znieczulane i cierpią potworny ból, kiedy są zagryzane żywcem, co jest przeznaczeniem większości z nich. Całkowita ilość cierpień będących co roku udziałem wszystkich żywych stworzeń przekracza wszelkie wyobrażenie. $\mathrm{W}$ ciągu minuty, jaką zajęło mi napisanie tego zdania, tysiące zwierząt zostało zjedzonych żywcem, tysiące uciekało przed śmiertelnym niebezpieczeństwem umierając ze strachu, tysiące było powoli drążonych od środka przez pasożyty, tysiące umierało w koszmarnych mękach z głodu, pragnienia i choroby. Tak musi być. Gdyby kiedykolwiek nadszedł czas powszechnej pomyślności i obfitości, automatycznie nastąpiłby wzrost populacji wszystkich stworzeń, co przywróciłoby naturalny stan zagrożenia głodem i śmiercią.

Dawkins podsumował swoje rozważania następująco:

Właśnie taki świat miał na myśli nieszczęśliwy poeta, A. E. Housman, pisząc:

Naturo, bezlitosna i bezwzględna,

Co o niczym nie wiesz i o nic nie dbasz.

DNA ani o niczym nie wie, ani o nic nie dba. DNA po prostu jest, a my tańczymy tak, jak nam zagra. ${ }^{19}$

\section{Zlo moralne}

Pomimo tego, że Dawkins posługuje się ostrą retoryką, nigdy nie grzeszył zbytnią znajomością filozofii czy chrześcijaństwa. Możliwe, że wbrew temu, co sądzi, wcale nie rozstrzygnął sprawy. Darwin myślał inaczej niż on i w dalszej części listu do Asy Graya kontynuował rozważania w punkcie, w którym skończył Dawkins:

\footnotetext{
${ }^{19}$ DAWKINS, Rzeka genów..., s. 191-193.
} 
A mimo to patrząc na ten wspaniały wszechświat, a zwłaszcza zastanawiając się nad naturą człowieka, nie mogę zadowolić się wnioskiem, że wszystko to jest wynikiem działania bezrozumnej siły. Skłonny jestem uznać, że wszystko jest rezultatem działania bezwzględnych praw, a poszczególne zjawiska — zarówno dobre, jak i złe - są pozostawione grze tego, co nazwalibyśmy przypadkiem. Nie znaczy to, aby ten wniosek zadowalał mnie w zupetności. Szczerze czuję, że całego tego zagadnienia umysł ludzki zgłębić nie jest w stanie. To tak jakby pies zastanawiał się nad poglądami Newtona. ${ }^{20}$

W duchu Darwina dajmy chrześcijanom szansę odpowiedzi na zarzuty i posłużmy się tradycyjnym rozróżnieniem na zło moralne i zło naturalne lub fizyczne. W pierwszą postać zła wpisuje się hitleryzm, w drugą - trzęsienie ziemi w Lizbonie. Zauważmy, że chrześcijanie mają tradycyjne wytłumaczenia genezy obu rodzajów zła. Dla nas istotna jest kwestia, czy darwinizm - mechanizm doboru naturalnego — obala któryś z tych kontrargumentów lub nawet oba.

Chrześcijańskie wyjaśnienie zła moralnego w świecie odnajdujemy w dziełach św. Augustyna. ${ }^{21}$ Bóg obdarzył nas wolną wolą, która jest wielkim darem czynienia dobra. Jednak posiadanie wolnej woli wiąże się również $\mathrm{z}$ wyborem zła. Mimo to lepiej mieć wolną wolę i móc czynić zło niż nie mieć jej wcale i nie móc podejmować samodzielnych decyzji. Interesują nas tutaj dwie kwestie. Po pierwsze, czy nauka, a więc i darwinizm, czyni wolną wolę niemożliwą? Po drugie, czy jest coś w samym darwinizmie, co każe odrzucić istnienie wolnej woli? Co się tyczy pierwszego pytania, to nauka i wolna wola mogą iść w parze, a nawet istnieją powody, dla których muszą one ze sobą współgrać. W myśl tę wpisują się rozważania Hume’a. ${ }^{22}$ Jeśli nie ma praw rządzących ludzkim zachowaniem, to nie jesteśmy wolni, gdyż możemy działać jedynie w sposób bezpodstawny i całkowicie niero-

\footnotetext{
${ }^{20}$ List Karola Darwina do Asy Graya z 22 maja 1860 roku, w: DARwIn, Autobiografia i wybór listów..., s. 217.

${ }^{21}$ Por. św. Augustyn, O państwie Bożym. Przeciw poganom ksiąg XXII, przeł. Wiktor Kornatowski, PAX, Warszawa 1977.

${ }^{22}$ Por. Dawid Hume, Traktat o naturze ludzkiej, przeł. Czesław Znamierowski, Fundacja Aletheia, Warszawa 2005.
} 
zumny. Dla kompatybilisty kluczowe jest rozróżnienie między wolnością a przymusem, nie zaś między wolnością a prawem. Człowiek zakuty w kajdany nie jest wolny, tak samo jak nie można nazwać wolnym człowieka zahipnotyzowanego. Prawdą jest, że podlegają oni prawu, ale podlega mu także człowiek nieskrępowany kajdanami i nieznajdujący się pod wpływem hipnozy.

Szukając odpowiedzi na drugie pytanie, rozważmy, czy teoria Darwina zawiera jakiś specyficzny pierwiastek, który sprawia, że wszyscy jesteśmy pod wpływem hipnozy, tyle że genetycznej. Posiłkując się słowami krytyków, takich jak harwardzki biolog Richard Lewontin, zapytajmy, czy darwinizm zaprzecza istnieniu wolności, uznając ludzi za „genetycznie zdeterminowanych"? ${ }^{23} \mathrm{~W}$ myśl determinizmu genetycznego nasze uczucia i działania są efektem oddziaływania genów, a tym samym nie istnieje wolność, nie jesteśmy dobrzy lub źli. Hitler nie był niczemu winny. Miał po prostu zły genotyp, który przetrwał za sprawą doboru naturalnego. Wińmy więc mechanizm, nie człowieka. Podobnie nie powinniśmy gloryfikować Matki Teresy, ponieważ miała ona po prostu dobry genotyp (zestaw genów).

Powyższa argumentacja jest jednak nie do utrzymania. Oczywiście niektóre zachowania są uwarunkowane genetycznie. Weźmy na przykład mrówki. Owady te zaprogramowane są przez geny wykształcone w procesie doboru naturalnego. Filozof Daniel Dennett podaje interesujący przykład determinizmu genetycznego, który (z uwagi na przejawiające go stworzenia) nazywa ,sphexowością”. Osa z rodzaju Sphex wykopuje w piasku norkę, następnie znajduje i wciąga do niej świerszcza, którego uprzednio żądli, ale nie po to, by go zabić, lecz spowodować paraliż. Osa składa przy swej ofierze jaja, po czym zakopuje norkę i odlatuje, nigdy już nie powracając w to miejsce. Zdawać by się mogło, że mamy tu zadziwiający przykład namysłu i intencjonalności, a jednak, gdy w rytuale osy coś pójdzie nie tak, da się dostrzec mechaniczną naturę całego procesu.

\footnotetext{
${ }^{23}$ Por. Richard C. Lewontin, Biology as Ideology: The Doctrine of DNA, Anansi, Toronto 1991.
} 
Rutynowe zachowanie osy polega na pozostawieniu sparaliżowanego świerszcza przed norką, zbadaniu, czy jej wnętrze jest odpowiednio przygotowane, wyjściu z norki i wciągnięciu świerszcza do środka. Jeśli podczas wstępnej inspekcji norki ofiara zdoła przemieścić się o kilka centymetrów, osa wyjdzie na zewnątrz, ponownie przyniesie świerszcza, zostawi go przed norką i powtórzy procedurę badania jej wnętrza.

Ten rytuał trwać może w nieskończoność: „Osa nigdy nie pomyśli, by wciągnąć świerszcza do norki. Raz cała procedura powtarzana była nawet czterdziestokrotnie, zawsze $\mathrm{z}$ tym samym skutkiem". ${ }^{24}$

Jednak Dennett (kolejny, obok Dawkinsa, gorliwy zwolennik teorii Darwina i krytyk chrześcijaństwa) podkreśla, że ludzie nie są zdeterminowani genetycznie w ten sam sposób, co osy. Stojąc w obliczu wyborów, mamy zdolność podejmowania decyzji, które zawsze możemy zrewidować i zmienić, jeśli sprawy potoczą się nie po naszej myśli. Takie możliwości uzyskaliśmy w toku ewolucji. W żargonie ewolucjonistów mówi się, że osy i mrówki są produktem „doboru r”. Mają one bardzo liczne potomstwo i mogą sobie pozwolić na utratę jego części. Ludzie natomiast podlegają „doborowi K”. Wydają na świat ograniczoną ilość potomstwa i w razie jakichś przeciwności nie mogą pozwolić sobie na jego utratę. Tak więc, aby uniknąć problemów, człowiek posiada zdolność podejmowania decyzji. Dlatego też obdarzony jest dużym mózgiem.

Rozmnażające się w olbrzymich ilościach mrówki i osy przypominają tanie pociski rakietowe, które nie mogą zmienić raz obranej trajektorii lotu. Natomiast ludzie są jak drogie pociski rakietowe — produkuje się ich niewiele, ale mogą one zmienić kurs nawet w trakcie lotu, o ile tylko cel, który mają osiągnąć, zmieni kierunek, prędkość lub cokolwiek innego. W odróżnieniu od tanich pocisków rakietowych, te drogie cechuje swoboda działania - wymiar wolności. Oba rodzaje pocisków, podobnie jak mrówki, osy i ludzie, podlegają prawom przyrody. Mimo zdeterminowania genetycznego dysponujemy

\footnotetext{
${ }^{24}$ Dean Wooldridge (cyt. za: Daniel C. Dennett, Elbow Room, MiT Press, Cambridge, Massachusetts 1984, s. 82).
} 
wolnością, którą zawdzięczamy właśnie doborowi naturalnemu. Tym samym argument ze zła przeciw istnieniu wolnej woli upada — przynajmniej, jeśli jego podstawą jest darwinizm.

\section{Zlo naturalne lub fizyczne}

Jest to główny argument Dawkinsa i tylko ktoś pozbawiony wrażliwości mógłby nie przyznać, że coś w tym jest. Darwinizm akcentuje aspekt bólu i cierpienia w świecie przyrody. Czy jednak istnienie naturalnego zła stanowi problem dla chrześcijaństwa? Tradycyjną odpowiedź przypisuje się zwykle wybitnemu niemieckiemu filozofowi Leibnizowi. Zwrócił on uwagę, że bycie wszechmocnym nie implikuje zdolności robienia czegoś, co jest niemożliwe. Bóg nie może sprawić, by $2+2=5$. Decydując się na stwarzanie za pomocą praw przyrody (a mogą istnieć dobre teologiczne powody ku temu), nie mógł też sprawić, by nie było fizycznego zła. Może być ono po prostu konsekwencją wyboru sposobu stwarzania.

Przykładowo, co pociągałaby za sobą zmiana praw przyrody rządzących procesem trawienia, tak by arszenik lub inna trucizna nie wpłynęły negatywnie na mój organizm? Czy arszenik, moja fizjologiczna konstytucja lub oba te czynniki nie musiałyby być zmienione $\mathrm{w}$ ten sposób, że w rezultacie byłyby różne od tego, co dziś nazywamy arszenikiem czy ludzkimi narządami trawiennymi? ${ }^{25}$

Paradoksalne i zarazem dość zabawne jest to, że Dawkins poniekąd wspiera tę linię argumentacji. Od dawna bowiem utrzymuje, że złożone przystosowanie może być wytworem prawa przyrody tylko wówczas, jeśli kierował tym mechanizm doboru naturalnego. Dawkins zauważa, że alternatywne mechanizmy (przede wszystkim lamarkowski), których konsekwencją jest przystosowanie organizmów do środowiska, nie działają w rzeczywistym świecie, te zaś, które nie tworzą przystosowań (zwłaszcza ewolucja skokowa postulowana przez saltacjonizm), są nieodpowiednie: „Jeśli jakaś forma życia przejawia zło-

\footnotetext{
${ }^{25}$ Bruce R. ReIchenBach, „Natural Evils and Natural Laws: A Theodicy for Natural Evil”, International Philosophical Quarterly 1976, vol. 16, s. 185.
} 
żoność adaptacyjną, znaczy to, że musi oddziaływać na nią mechanizm ewolucyjny zdolny do jej wytwarzania. Mechanizmy ewolucyjne mogą być zróżnicowane, ale o ile nie ma innej ogólnej teorii opisującej życie we Wszechświecie, to mogę się założyć, że zawsze będzie ono rozpoznawalne jako życie darwinowskie". ${ }^{26}$ Krótko mówiąc, jeśli Bóg stwarzał za pośrednictwem prawa przyrody, to musiało być to prawo darwinowskie. Nie było innej możliwości. (To oczywiście nie znaczy, że wiedząc o nastaniu bólu i cierpienia w świecie, Bóg postąpił słusznie, powołując świat do istnienia. Jest to jednak inna kwestia, niemająca nic wspólnego z darwinizmem.)

Innymi słowy, tak jak rozumowanie arcydarwinisty $i$ ateisty Daniela Dennetta można wykorzystać do obrony chrześcijaństwa w obliczu zła moralnego, tak teraz rozumowanie arcydarwinisty i ateisty Richarda Dawkinsa może posłużyć do obrony religii chrześcijańskiej w obliczu zła fizycznego!

\section{Zakończenie}

Wspomniałem, że nie mam bardziej pozytywnego nastawienia względem wiary religijnej niż Richard Dawkins, i jest to prawda. Moim celem nie była obrona chrześcijaństwa, lecz uczciwości darwinisty, który jednocześnie chciałby być chrześcijaninem. Pod pewnym względem różnię się jednak od Dawkinsa w sprawach wiary. On jest przekonany, że Boga nie ma i nie istnieje nic poza tym, co dostępne jest poznaniu naukowemu. To zdeklarowany ateista. Jeśli o mnie cho$\mathrm{dzi}$, to jestem ateistą $\mathrm{w}$ stosunku do chrześcijaństwa - nie potrafię wierzyć, że Jezus skonał na krzyżu za moje grzechy — jednak w szerszym wymiarze wolę uważać siebie za agnostyka czy sceptyka. Być może istnieje coś więcej. Być może nie. Nie mam pojęcia. Wiem natomiast, że wedle darwinizmu jestem przedstawicielem rzędu naczelnych, posiadającym takie cechy przystosowawcze, które pozwoliły mi

\footnotetext{
${ }^{26}$ Richard Dawkins, „Universal Darwinism”, w: D.S. Bendall (ed.), Molecules to Men, University of Cambridge Press, Cambridge 1983, s. 423.
} 
(a raczej moim przodkom) zejść z drzewa, żyć na równinach, zdobywać pożywienie (prawdopodobnie padlinę) i bronić się przed wrogami (zapewne innymi hominidami). Nie mam powodów, by sądzić, że wyposażony jestem w cechy przystosowawcze niezbędne do zrozumienia tajemnic Wszechświata. Mimo to jestem pewien, że mam cechy przystosowawcze, które są niezbędne do tego, abym żywił zuchwałe przekonanie o posiadaniu przeze mnie takich właśnie cech. Dobór naturalny nie sprzyja intelektualnej pokorze.

Pragnę jedynie zaznaczyć, że darwinizm nakazuje mi skromność w kwestii tego, co wiem i co mogę wiedzieć. ${ }^{27}$ Rzeczywistość może mieć w istocie bardzo niezwykły charakter. Lepiej więc nie ryzykować i pozostać agnostykiem. Na poparcie tych słów przytoczę wypowiedź innego darwinisty, który najwyraźniej podziela moje zdanie: „Współczesna fizyka poucza nas, że prawda przeczy naszym intuicyjnym wyobrażeniom czy też przekracza zakres możliwości ludzkiego intelektu, który niegdyś rozwinął się, aby nasi przodkowie mogli radzić sobie z obiektami średniej wielkości, poruszającymi się ze średnią prędkością i przemierzającymi średnie odległości w Afryce". ${ }^{28}$ Amen!

Michael Ruse

\footnotetext{
${ }^{27}$ Por. Michael Ruse, Taking Darwin Seriously: A Naturalistic Approach to Philosophy, 2nd ed., Prometheus, Buffalo, New York 1998; Michael Ruse (ed.), Mystery of Mysteries: Is Evolution a Social Construction?, Harvard University Press, Cambridge, Massachusetts 1999

${ }^{28}$ Richard Dawkins, A Devil's Chaplain: Reflections on Hope, Lies, Science and Love, Houghton Mifflin, Boston and New York 2003, s. 19.
} 